\title{
Kerajaan dan Komunitasnya: Sejarah dan Teori \\ Keberadaan Komunitas Bahari di Masa Sriwijaya
}

\author{
Nurrohim \\ IAIN Purwokerto \\ Jl. A. Yani No.40A, Karanganjing, Purwanegara, Kabupaten Banyumas, Jawa Tengah \\ cairowanderer14@gmail.com
}

\begin{abstract}
Kingdom and Community: History and Theory of the existence of a Maritime Community in the Srivijaya Period. Srivijaya is one of the greatest kingdom that once triumphed in the Indonesian archipelago. Its location is believed to be on the outskirts of the Musi River reinforces some theories about their domination of maritime trade routes in the archipelago at that time. This study aims to reconstructthe theories and historical version of the development of maritime community in the territory of Srivijaya kingdom. The method used is the historical method because it deals with events or objects of the past. Comparative analysis is also needed because of the theory about the existence of maritime society. The results of the research using the method above has found that the possibility of maritime society during the Srivijaya kingdom is very strong. This is corroborated by historical data from some travel records to the territory of Srivijaya at that time. One of them was Chau Ju-Kua, an official of the Song Dynasty who wrote in his book Chu-fan-chi about the Srivijaya's peoples who were living in floating housesalthough he himself only gets the information from travelers who come to Sriwijaya and meet him in Guangzhou, one of the biggest city in south China.
\end{abstract}

Keywords: Srivijaya, Maritime Society, Orang Laut.

Abstrak: Kerajaan dan Komunitasnya: Sejarah dan Teori Keberadaan Komunitas Bahari di Masa Sriwijaya. Sriwijaya adalah satu dari beberapa kerajaan besar yang pernah berjaya di wilayah Nusantara. Letaknya diyakini berada di pinggiran sungai Musi menguatkan beberapa teori tentang penguasaan Sriwijaya terhadap jalur perdagangan di Nusantara kala itu. Penelitian ini bertujuan untuk menggali kembali berbagai teori dan versi sejarah tentang berkembangnya komunitas bahari di wilayah kerajaan Sriwijaya. Metode yang digunakan adalah metode historis analisis objek kajian berkenaan dengan peristiwa atau objek masa lampau. Analisis komparatif juga dibutuhkan karena berkenaan dengan teori tentang keberadaan masyarakat bahari. Dari hasil penelitian didapatkan bahwa kemungkinan adanya masyarakat bahari pada masa kerajaan Sriwijaya adalah sangat kuat. Hal ini didukung dengan data historis dari beberapa catatan pelawat ke wilayah Sriwijaya saat itu. Salah satu di antaranya adalah Chau Ju-Kua, seorang pegawai resmi Dinasti Song yang menuliskan dalam bukunya Chu-fan-chi tentang masyarakat Sriwijaya yang saat itu tinggal di atas rumahrumah apung meski ia sendiri hanya mendapatkan informasi tersebut dari para pelancong yang datang ke Sriwijaya dan bertemu dengannya di Guangzhou, salah satu kota terbesar di Cina selatan.

Kata Kunci: Sriwijaya, Masyarakat Bahari, Orang Laut.

\section{Pendahuluan}

Sriwijaya di mata presiden pertama Republik Indonesia, Soekarno adalah satudari dua pondasi acuan pembentukan Negara Republik Indonesia di samping Majapahit. Kekuasaan yang diyakini terbentang di hampir seluruh wilayah Pulau Sumatra dan sebagian Pulau Jawa serta sebagian be- sar wilayah yang sekarang menjadi negaranegara di kawasan Asia Tenggara, menjadi alasan kuat penyebutan Sriwijaya sebagai pondasi terbentuknya Negara Indonesia.

Pembahasan tentang Kerajaan Sriwijaya sampai sekarang masih menjadi suatu obyek penelitian yang menarik bagi para peneliti lokal maupun internasional. Hal 
ini berkenaan dengan obyek kajian yang sangat luas dan berbanding terbalik dengan minimnya atau belum ditemukannya sumber-sumber yang komprehensif tentang keberadaan Sriwijaya. Informasi tentang keberadaan Sriwijaya, umumnya didasarkan kepada beberapa prasasti seperti Prasasti Talang Tuo, Kedukan Bukit dan beberapa prasasti lainnya yang masih belum bisa menjawab pertanyaan-pertanyaan dari para sejarawan. Informasi dari prasastiprasasti tersebut kemudian dilengkapi dengan catatan-catatan dari pelancongpelancong dari luar Nusantara seperti ITsing, Chau Ju-Kua, Tomes Pires dan yang lainnya.

Meski sumber tertulis tentang Kerajaan Sriwijaya sangat minim. Namun, hal ini tidak bisa menjadi pembenaran jika terdapat klaim bahwa tradisi menulis masa tersebut minim atau ilmu pengetahuan di masa tersebut kurang maju. Hal ini disanggah dengan ditemukannya penjelasan dalam beberapa catatan bahwa Kerajaan Sriwijaya sempat membuat kerja sama dengan Kerajaan Chola di India. Bahkan, kafilah-kafilah dagang dari Cina diberitakan singgah dulu ke wilayah Sriwijaya atau dulu disebut sebagai Svarnadwipa sebelum menujuke wilayah India. Beberapa teori yang berkembang menyebutkan bahwa kafilah dagang ini berisikan para pendeta maupun siswa yang memang berniat belajar tentang ajaran Buddha, khususnya aliran Buddha Mahayana di wilayah Sriwijaya sebelum akhirnya melakukan perjalanan suci ke India. I-Tsing sendiri melakukan hal tersebut untuk secara konsen belajar tata bahasa Sanskritdi sekitaran abad ke $7 .{ }^{1}$

Perdebatan tentang pusat pemerintahan Sriwijaya sampai saat ini juga belum menemukan titik terang. Sejarawan kemudian seolah bersepakat bahwa ibu kota Sriwijaya dan tempat terbentuknya kerajaan Sriwijaya pertama adalah di wilayah Palembang sekarang (di sepanjang pinggiran Sungai Musi) meski belum diketahui juga di mana letak tepatnya. Ibu kota ini kemudian diyakini dipindahkan ke wilayah Jambi karena alasan pendangkalan Sungai Musi di wilayah kota pemerintahan sebelumnya. Pemindahan juga diyakini dengan ditaklukkannya Kerajaan Melayu di Jambi. Oleh Slamet Muljana dalam buku Sriwijaya menyebut bahwa pendapat-pendapat dan bukti arkeologis maupun bukti tertulis menunjukkan penguatan bahwa Jambi lebih tepat disebut sebagai ibu kota dari Kerajaan Sriwijaya dan bukan Palembang. Hal ini dikuatkan dengan pandangan geomorfologi ${ }^{2}$ yang lebih menujukkan bahwa Jambi pantas disebut sebagai wilayah yang mampu memegang peranan yang kuat dalam pelayaran yang melewati Selat Malaka yang berlayar ke utara menuju Tiongkok dan ke arah timur menuju Pulau Sunda. ${ }^{3}$ Sebaliknya, perahu-perahu yang berlayar dari lautan selatan dan laut Jawa menuju India dan negara-negara lainnya di sebelah barat harus berlayar melalui Jambi.

Satu teori yang ingin secara fokus diteliti adalah berkenaan dengan keberadaan komunitas perairan atau kelompok masyarakat yang hidup di atas air. Dasar yang digunakan adalah catatan dari seorang pegawai pengurus peradagangan laut di abad ke 13 $\mathrm{M}$ dari Dinasti Song, Chau Ju-Kua berjudul Chu-fan-chi yang menuliskan bahwa masyarakat Svarnarnadwipa saat itu tinggal di atas rumah-rumah yang terapung. Teori ini bisa menjadi landasan dalam pembahasan serta pencarian fakta baru tentang kehidupan sosial pada masa pemerintahan Sriwijaya dari masa awal berdirinya sampai masa runtuhnya. 


\section{Pembahasan}

\section{A. Komunitas Bahari Masa Sriwijaya}

Bahari mengandung beberapa makna, bisa diartikan berhubungan dengan perairan ataupun berhubungan dengan laut. ${ }^{4}$ Dalam KBBI bahari sering disinonimkan dengan maritim.Bahari dapat diartikan (1) kuno; dahulu kala, (2) elok sekali; indah, dan (3) mengenai laut. Aspek kebaharian atau kemaritiman kemudian oleh para ekspert didekatkan hubungannya dengan perdagangan dan pelayaran di wilayah perairan.

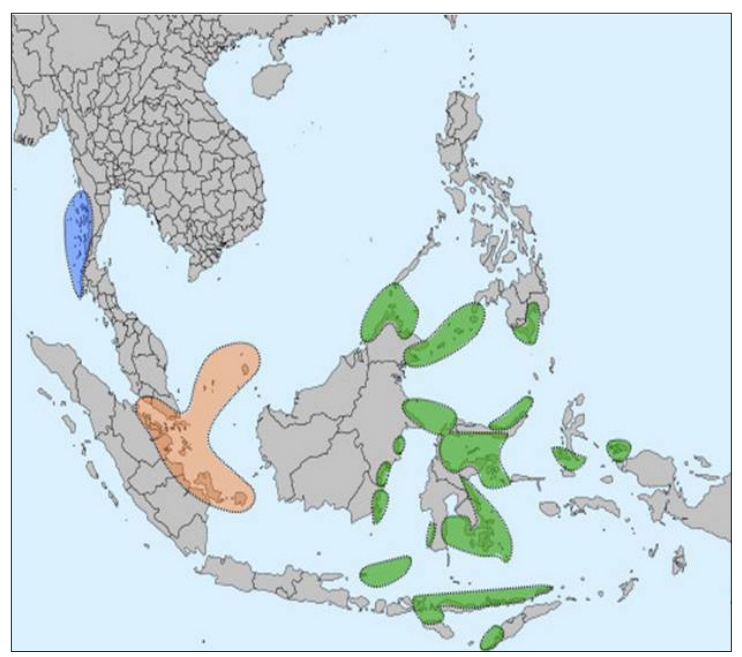

\section{Gb. 1.Komunitas bahari di Asia Tenggara. Diambil dari https://theaquaticape.org/sea-nomads/}

Sebagaimana peta di atas, diAsia Tenggara terdapat tiga macam komunitas pengembara lautan: Moken, yang tinggal di pantai barat Burma dan Thailand, Orang Laut, yang tinggal di Thailand selatan, Malaysia selatan dan Indonesia bagian barat, dan Sama-Bajau, yang tinggal di selatan Filipina, Malaysia timur, dan Indonesia tengah. Mereka memiliki sejarah dan bahasa yang berbeda dan menjadi nomaden atau semi-nomaden dengan alasan yang berbeda Namun, mereka semua secara tradisional disebut sebagai "gipsi laut".

Moken mungkin merupakan kelompok yang tertua.Mereka diyakini berasal dari Cina selatan sekitar 4000 tahun yang lalu. Mereka tinggal di pantai barat Burma dan Thailand, mereka memiliki bahasa sendiri, agama mereka sendiri dan secara historis mencari nafkah sepenuhnya dari berburu dan meramubaik di laut maupun di garis pantai. Saat ini mereka lebih cenderung berdagang untuk mencukupi kebutuhan mereka.

Moken mulai mencuri perhatian internasional setelah tsunami di Asia Tenggara pada tahun 2004, ketika tidak ada satupun orang Moken yang meninggal walaupun mereka tinggal di lautan yang terbuka. Mereka memiliki pengetahuan tentang peringatan diniakan adanya tsunami dan apa yang harus diperhatikan di laut. Banyak orang tua Moken juga pernah mengalami tsunami-tsunami kecil. ${ }^{6}$

Pada awal tahun 2000, Anna Gislén melakukan penelitian terhadap visi anakanak Moken di bawah air di Thailand, setelah mendapat saran dari Profesor Erika Schagatay. Dia mendapatkan temuan yang menarik yang menunjukkan bahwa anak-anak Moken melihat jauh lebih baik di bawah air daripada anak-anak Eropa, karena mereka dapat menyempitkan mata mereka di bawah air. Kemudian dia juga menemukan bahwa setiap anak dapat melihat dengan baik di bawah air setelah melalui pelatihan. ${ }^{7}$

Orang Laut tinggal di Indonesia bagian barat dan Thailand selatan. Mereka dulu juga tinggal di sekitaran pantai wilayah Singapura tetapi kemudin terusir dengan kemajuan kota yang semakin pesat. Orang Laut secara historis adalah pedagang dan nelayan, dan mereka memainkan peranan penting dalam perdagangan rempahrempah pada abad ke-15 dan 16 sebelum kekuatan kolonial Eropa mengubah dan menguasai rute perdagangan. Orang Laut 
memiliki agamanya sendiri dengan unsur animisme di dalamnya. ${ }^{8}$

Bajau Laut adalah kelompok terbesar pengembara laut, dan mereka tinggal di Malaysia bagian timur, Filipina selatan, di sebagian besar wilayah Indonesia tengah dan di Brunei Darussalam. Kelompok ini masih dapat ditemukan di pesisir wilayahwilayah tersebut. Mereka mencari penghidupan dengan mencari ikan (tombak, jaring, dan memancing). Sejarah mereka mirip dengan sejarah Orang Laut, meski antara keduanya tidak memiliki hubungan secara linguistik. Bajau Laut juga terlibat dalam perdagangan rempah-rempah dan mereka menguasai rute timur. Kelompok Sama-Bajau diakui sebagai salah satu suku Muslim di Asia Tenggara, tetapi banyak Suku Bajau laut yang lebih mempertahankan kepercayaan tradisional mereka. Aspek animisme Bajau Laut mirip dengan Orang Laut dengan persembahan beras dan kelapa untuk menenangkan roh-roh. ${ }^{9}$

Keberadaan komunitas bahari di wilayah Kerajaan Sriwijaya disebutkan dalam beberapa teori. Teori pertama mendasarkan kepada keberadaan catatan Chau Ju-Kua dalam buku hasil catatan perjalannanya Chu-fan-chi bahwa masyarakat Sriwijaya saat itu tinggal di rumah-rumah apung. Keberadaan teori-teori tentang model pemukiman masyarakat masa Sriwijaya sejalan dengan berkembangnya beberapa teori tentang ibu kota Kerajaan/ Kedatuan Sriwijaya.

Berdasar deskripsi yang dikemukakan oleh Sather tentang komunitas masyarakat atau yang ia sebut sebagai Sea Nomads yang hidup di wilayah Asia Tenggara, penulis meyakini bahwa Orang Lautyang tinggal di Indonesia bagian barat dan Thailand selatan dapat diyakini sebagai nenek moyang dari masyarakat Sriwijaya yang hidup di perairan atau di rumah-rumah apung sebagaimana yang dikemukakan oleh Chau Ju-Kua di atas.

\section{B. Latar Belakang Terbentuknya Komu- nitas Bahari masa Sriwijaya}

Terdapat beberapa teori tentang alasan di balik kehidupan bahari atau masyarakat maritim di era Sriwijaya ini. Studi masyarakat maritim di seluruh dunia pada abad ke-10 hingga 17 menunjukkan bahwa pelabuhan-pelabuhan umumnya selalu menjadi pusat berkembangnya peradaban. Sungai dan laut adalah transportasi utama pada zaman itu, jadi tidak mengherankan apabila kemudian terbentuk komunitaskomunitas masyarakat di wilayah tersebut. Semakin dekat populasi dengan pelabuhan semakin mudah mereka mendapatkan komoditi. Barang yang diperdagangkan yang datang dari wilayah lain menjadi daya tarik pertukaran pada masa tersebut. Dapat disebutkan bahwa pusat perekonomian saat itu tergantung dari besar kecilnya pelabuhan di tempat tersebut. Semakin besar sebuah pelabuhan dan semakin beragamnya bangsa yang datang melandasi semakin makmurnya kehidupan di wilayah tersebut. Pelabuhan-pelabuhan yang mulai terbentuk dengan terjadinya interaksi antara kerajaan Funan dengan Bangsa India kemudian membentuk komunitas-komunitas di wilayah pelabuhan tersebut. ${ }^{10}$

Yang menjadi pertanyaan kemudian adalah kapan mulai terbentuknya komunitas bahari ini? Apa saja yang melandasinya? Serta bagaimana kehidupan sosial masyarakat bahari pada masa tersebut? Tidak terdapat banyak catatan yang membahas tentang waktu pasti terbentuknya komunitas masyarakat bahari ini. Umumnya dalam sejarah nusantara, komunitas yang sering disebut mahir dalam hal kelautan dan pelayaran adalah suku Bajo dari Sulawesi. 
ChauJu-Kua memang telah mengemukakan dalam catatannya di Chu-fan-chi bahwa masyarakat Sriwijaya pada abad ke 13 hidup di perairan serta tinggal di rumahrumah apung (floating houses) di sekitar abad ke-13. ${ }^{11}$ Meskipun catatannya ini tidak ia dapatkan langsung dengan melancong ke wilayah Sriwijaya. Catatan tentang Palembang atauyang ia sebut San-fo-tsi ia dapatkan dari laporan beberapa pedagang yang telah sampai ke wilayah Palembang atau San-fo-tsi ketika ia ditunjuk oleh Dinasti Song untuk mengurusi perdagangan laut di wilayah Guangzhou, Propinsi Fujian di tahun 1224. Pedagang-pedagang yang sampai ke wilayah Fujian ini yang menjadi sumber bagi catatan Chau Ju-Kua yang kemudian dibukukan menjadi kumpulan tulisan dalam buku Chu-Fan-Chi.

Hirth kemudian mencoba menghubungkan deskripsi Chau Ju-Kua ini dengan keadaan dari Kanton yang populasinya pada saat itut digambarkan banyak berpencar di luar tembok kota serta hidup di atas raft (kayu-kayu yang dirakit menjadi satu sebagai alas apung dan kemudian diberi dinding dan atap). Deskripsi seperti ini yang diyakini diambil oleh Chau Ju-Kua sebagai gambaran terhadap keadaan masyarakat bahari di masa Sriwijaya di San-fo-tsi saat itu. ${ }^{12}$

Alasan pertama yang menjadi dianalisis oleh Hirth dan Rockhill adalah penghindaran terhadap pembayaran pajak tanah dan bangunan. Dengan dibuatnya rumah apung di sekitaran sungai Musi atau di atas perairan pada masa Sriwijaya tersebut adalah untuk menghindari pembayaran pajak yang diyakini saat tersbut banyak dibebankan kepada rakyat, sehingga banyak rakyat Sriwijaya di masa tersebut yang tinggal di luar dinding kota dari pusat pemerintahan dan hidup di luaran dinding serta membuat rumah-rumah apung.

Kembali kepada teori tentang keberadaan laut bagi peradaban yang dikemukakan oleh Prancis Fernard Braudel. Memandang laut dapat menggunakan dua sisi strategis, yaitu sebagai peluang dan tantangan bagi sebuah negara atau peradaban yang ada di darat. Laut dapat berfungsi ganda yaitu dapat menjadi penghalang dalam satu sudut pandang, dan menjadi peluang dalam sudut pandang yang lain. Laut diyakini sebagai penghalang karena kepercayaan bahwa laut adalah akhir dari dunia dan tidak memberikan apa-apa kepada manusia. Sebagaimana yang terjadi pada abad pertengahan Eropa, ketika seseorang melakukan pelanggaran berat, hukuman yang paling berat diputuskan kepada pelakuknya adalah dibuang ke laut atau diasingkan dengan cara diusir menggunakan perahu ke perairan. Demikian juga terdapat kepercayaan kalau the edge of the world adalah berada di laut lepas.

Berbeda ketika muncul teori yang menyatakan bahwa adanya laut adalah sebagai peluang. Laut memungkinkan terjadinya persatuan dan menjadi sarana perhubungan dari satu pulau ke pulau yang lainnya..$^{13}$ Sedang pelayaran dan perdagangan di laut dalam perspektif ekonomi Smith dan Mill dapat menghasilkan dua keuntungan yang dinamis, yaitu; 1.Vent for Surplus (peluang bagi kelebihan SDA). Surplus yang dialami oleh suatu wilayah dengan adanya pelayaran dari satu pulau ke pulau yang lainnya memungkinkan barang-barang yang sebelumnya merupakan barang yang berlebih atau tidak dapat bermanfaat kemudian dapat bermanfaat di wilayah yang lain. Hal ini menjadi sisi positif bagi barter atau pertukaran barang dari satu wilayah dengan wilayah yang lain; 2. Highway of Learning atau Cross Culture, yaitu penyingkapan yang berujud pengalihan pengetahuan dari satu kultur kepada kultur yang lain. ${ }^{14}$ 


\section{Orang Laut sebagai Moyang bagi Ma- syarakat Bahari}

Pembahasan tentang orang laut muncul dalam beberapa literatur Barat yang menyajikan data tentang kekuatan naval atau maririm Kerajaan Sriwijaya. Sebagaimana disebutkan, bahwa di tahun $683 \mathrm{M}$, Sriwijaya telah dicatatkan memiliki kekuatan perang sebanyak 20.000 tentara sebagaimana dikemukakan oleh George Coedes dalam karya yang berjudnul "A Possible Interpretation or the Kedukan Bukit" (Palembang) Inscription". Sebagian besar di antaranya beranggotakan orang laut. Hal ini bertujuan untuk memperkuat kontrol Sriwijaya di wilayah Sumatra maupun Semenanjung Malaysia. Wilayahnya yang mencakup daratan dan lautan serta untuk memperkuat kontrol penguasaan di pelabuhan dan bandar-bandar dagang maka dibutuhkan kekuatan militer yang kuat.

Orang laut diperkirakan dari awal berada di sebelah tenggara pulau Sumatra serta di sekitaran pantai selata Malaka yang memanjang dari pantai negara Singapura, Malaysia sampai Thailand sekarang yang berseberangan dengan Pulau Sumatra. Orang-orang laut ini oleh Tome Pires ketika melakukan pelayaran ke Nusantara ia sebut sebagai Celates di tahun $1511 \mathrm{M}$. Mereka yang disebut celates inilah yang diyakini sebagai anak turun dari orang laut yang sempat disebut dalam sejarah Sriwijaya, meskipun Sriwijaya telah runtuh pada abad ke 14. Keberadaan orang laut atau oleh Sather disebut sebagai sea nomads ia yakini selalu berpindah dari satu wilayah pantai ke wilayah pantai yang lainnya, namun oleh Tomes Pires ia gambarkan tinggal di sekitaran pantai di wilayah yang berdekatan dengan Malaka maupun dengan Palembang atau Pulau Sumatra.
Orang laut yang oleh Entre d'Ethnotechnologie en Milieux Aquatiques in Parisdisebut sebagai Aquatic Populations diyakini telah menjalin hubungan yang baik dengan penguasa Sriwijaya sehingga keduanya seolah berada dalam ikatan mutualisme. Sriwijaya kuat di lautan dengan keberadaan orang laut, dan orang laut sendiri dapat bertahan hidup karena mendapat perlindungan dan kewenangan untuk tinggal di mana saja di bawah wilayah laut Sriwijaya. Kerajaan Sriwijaya diyakini telah mengfungsikan keahlian orang laut dalam ekspedisi-ekspedisinya ke wilayah baru yang melalui jalur laut serta memberi tawaran kepada mereka untuk bebas mengarungi wilayah lautnya dan membentuk komunitas orang laut baru di pantai-pantai wilayah yang dikuasai. Selain itu orang laut dikenal pula memiliki skill yang mumpuni dalam perang di darat maupun di laut. O.W Wolters mencuplik catatan Chau Ju-Kua tentang semangat perang tentara Sriwijaya yang ia gambarkan keganasannya yang tidak tertandingi oleh bangsa lain pada masa tersebut.

Sepotong bukti yang mungkin bisa menjelaskan hubungan antara penguasa Sriwijaya dan orang-orang laut adalah prasasti Telaga Batu, yang ditemukan di dekat sebuah sumur, tanggalnya yang tidak diketahui, di sudut barat pulau Sabukingking, sekitar 300 meter dari Geding Suro. Prasasti ini memberikan pengetahuan tentang cara kerajaan diatur dan ditertibkan dan kesatuan yang dipertahankan di dalamnya. Wolters menunjukkan bahwa kehadirannya di situs ini merupakan indikasi pusat kerajaan. Tulisan itu, yang terdiri dari dua bagian, berisi rumusan yang rumit tentang kutukan/sumpah dalam bahasa Melayu Kuno dankutukan/ sumpah lain yang lebih pendek, bagian pertama dari apa yang dikenal sebagai Ba- 
hasa B. ${ }^{15}$ Bahasa B ini menurut Obdeyn, mungkin merupakan bahasa Mingakabau lama; Damais mengakui kesamaannya dengan Malagasi, Jawa dan Cham, sementara Van Naerssen lebih mengidentifikasi bahwa itu adalah bahasa orang laut. Jika kita berasumsi bahwa pengikut penguasa Sriwijaya adalah orang Melayu dari pantai timur Sumatera dan orang laut, maka logis untuk menerima kesimpulan Van Naerssen dan menganggap bahwa prasasti Telaga Batu ditujukan kepada kedua kelompok ini. Semua tiga kutukan/sumpah, Telaga Batu, Kota Kapur dan Palas Pasemah, merupakan prasasti yang dituliskan dalam bahasa Melayu Kuno dan Bahasa B.

Isi prasasti Telaga Batu dapat dibagi menjadi tiga bagian utama: bagian pertama adalah doa untuk semua dewa; bagian kedua adalah kutukan bagi semua penjahat, termasuk mereka yang berkomplot melawan raja dan kerajaan; yang ketiga adalah berkah bagi mereka yang tunduk pada kekuasaan Sriwijaya. Bentuk batu di mana prasasti Telaga Batu diukir dan naga berkepala tujuh yang diukir dengan relief di atas prasasti menunjukkan bahwa itu memiliki fungsi tambahan. Karena ditemukan di dekat sumur, diyakini bahwa itu pasti digunakan untuk upacara pengambilan sumpah. Air pasti telah dituangkan di atas batu dan dikumpulkan dalam wadah di bawah prasasti. Air kemudian akan diminum oleh para pengambil sumpah, mungkin para datu, pemimpin dan gubernur yang disebutkan dalam prasasti. ${ }^{16}$ Upacara sumpah ini pastilah hidup dalam ingatan orang Melayu dan diceritakan kembali dalam Sejarah Melayu, meskipun dalam bentuk yang berbeda. Yang terakhir mengacu pada sumpah antara Sang Sapurba, mewakili penguasa, dan Demang Lebar Daun, mewakili rakyatnya, yang mungkin termasuk orang-orang laut.
D. Komunitas Masyarakat Bahari Sriwijaya; Antara Orang Suku Laut dan Bajak Laut

Komunitas masyarakat yang hidup di atas perairan pada masa kekuasaan Sriwijaya memang telah dapat dibuktikan keberadaanya melalui laporan Chau-Ju-Kua maupun catatan Tomes Pires ketika Portugal berhasil mendarat di wilayah pantai Pulau Sumatra. Namun, belum terdapat banyak laporan tentang jumlah mereka dan bagaimana cara mereka hidup serta tatanan sosial kemasyarakatan laut saat tersebut. Yang tercatat sekarang adalah keberadaan sisa-sisa orang laut yang hidup di sekitaran pesisir pantai di Kepulauan Riau.

Menurut teori Wolters, Orang Suku Laut selain menjalani hidupnya sebagai sekutu dari Kerajaan Sriwijaya dan mengikuti berlangsunya perang yang dilakukan dalam kehidupan kesehariannya hidup dari mencari ikan maupun berdagang. Joseph Campo dalam sebuah artikelnya yang dimuat oleh Journal of Southeast Asian Studies menuliskan bahwa sea habitants atau ada yang menyebutnya sebagai sea nomads/ orang laut dapat dibagi ke dalam beberapa karakteristik dan tidak bisa disamakan dengan keberadaan perompak atau bajak laut di sekitaran abad ke 18-19 M. ${ }^{17}$

Campo menyebutkan bahwa keberadaan perompak laut ini malah yang menyebabkan semakin terpinggirkannya komunitas orang laut. Keberadaan kekuasaan pelayaran Eropa seperti Belanda dan Inggris semakin meminggirkan pula keberadaan masyarakat Orang laut. Orang laut yang oleh Campo ia sebut memiliki kekuatan di laut pada masa sebelumnya secara perlahan-lahan mulai kehilangan pengaruhnya. Keberadaan perompak laut sendiri oleh Campo ia pisahkan dari komunitas orang laut. Bajak laut ia deskripsikan merupakan kumpulan dari orang-orang berperahu yang hanya 
mencari keuntungan ekonomi atau mencari pengaruh politik dengan menjarah kapal-kapal yang lewat. Selain itu, Campo juga menambahkan kalau bajak laut yang mulai menjamur di wilayah perairan di sekitar Selat Malaka dapat dimungkinkan juga merupakan sekumpulan orang-orang atau pelaut yang melakukan tindak kriminal di daratan kemudian diasingkan ke lautan. ${ }^{18}$

Meski pada deskripsi selanjutnya Campo menunjukkan bahwa Orang laut juga melakukan penyerangan terhadap beberapa rombongan kapal yang datang, namun tujuannya tak lain adalah sebagai bentuk kesetiaan terhadap pimpinannya tersebut. Penyerangan selalu harus merupakan perintah dari penguasa di atas mereka. Hal ini kemudin berbeda ketika muncul golongan pelaut yang oleh Campo ia sebut sebagai Ilanun Peoples yang kemudian bekerjasama dengan Pangeran Malaysia. Ilanun adalah salah satu komunitas orang laut juga, namun berasal di sekitaran pesisir pantai di Sulu, Filipina sekarang. Ilanun ia gambarkan sebagaimana predator yang selain merampok juga menjarah secara membabi-buta. Hal inilah yang kemudian melahirkan persepsi kalau orang laut adalah semacam parasit yang harus cepatcepat disingkirkan. Padahal dalam perspektif Campo, Orang laut terdiri dari bermacam karakteristik yang meski memiliki beberapa persamaan, namun di sisi yang lain juga memiliki perbedaan.

Dari uraian di atas penulis mendapatkan beberapa informasi berharga, meski merupakan analisis yang dilakukan oleh Jospeh Campo, namun cukup menarik menjadi dasar dalam membahas tentang keberadaan komunitas Bahari di masa Sriwijaya yang masanya masih jauh sebelum keberadaan para perompak laut tersebut. Informasi tersebut kembali dapat menjadi sanggahan tentang beberapa tuduhan bahwa nenek moyang orang laut yang berada di beberapa pesisir pantai Indonesia sekarang ini atau yang tinggal di rumah apung di beberapa pinggiran sungai bukanlah keturunan dari bajak laut atau perompak laut yang tidak mengenal aturan. Oleh Mary Sommer Heidhues dalam bukunya Southeast Asia: A Concise History menuliskan bahwa orang laut memang diyakini berasal dari suku perompak, namun dalam perjalanan setelahnya mereka dikenal sebagai komunitas masyarakat yang sangat setia dengan janji terhadap penguasa wilayahnya. Bahkan ia menuliskan bahwamasyarakat laut telah menajdi pengikut setia dari beberapa kerajaan seperti, Sriwijaya, Kesultanan Malaka dan Kesultanan Johor.

\section{Kesimpulan}

Pembahasan tentang Kerajaan Sriwijaya baru muncul di sekitaran abad ke 20 ketika George Coedes dengan karyanya yang berjudul The Indianized States of Southeast Asia menyebut keberadaannya yang berada di wilayah pulau Sumatra. Semenjak tulisan Coedes ini terbit, mulai berbondong-bondonglah para peneliti untuk menguak data-data sejarah yang berkaitan dengan kerajaan tersebut. Dengan semakin banyaknya para peneliti yang mencoba mengungkap sejarah kerajaan tersebut, semakin terungkaplah informasi-informasi yang berkaitan dengan Kerajaan Sriwijaya.

Salah satu data yang muncul adalah berkenaan dengan keberadaan komunitas bahari di wilayah kekuasaan Sriwijaya. Komunitas tersebut umumnya diyakini adalah sebagai nenek moyang dari keberadaan beberapa orang laut yang ada di wilayah Asia Tenggara. Berdasar catatan Chau-Ju-Kua dalam karya Chu-fan-chinya bertahun sekitar $1224 \mathrm{M}$ ditemukan informasi yang menyebut bahwa terdapat ma- 
syarakat Sriwijaya yang tinggal di luaran tembok pusat kota pemerintahan kerajaan. Bahkan terdapat banyak pula yang tinggal di rumah-rumah apung di perairan luar pusat kota. Hal ini sejalan pula dengan catatan Tomes Pires dalam Suma Orientalnya yang menyebut bahwa sekitaran pesisir pantai di Palembang dan Selat Malaka dipenuhi oleh adanya orang-orang yang hidup di atas perahu mereka. Ia kemudian menamakan mereka sebagai Celates atau orang-orang yang hidup di selat-selat.

Hirth kemudian mencoba menganalisis hasil terjemahannya terhadap karya Chau Ju-Kua dengan menyebut beberapa alasan atau latar belakang terbentuknya komunitas bahari di abad ke-13 $\mathrm{M}$ tersebut dapat terjadi karena faktor penghindaran terhadap pajak tanah yang dibebankan oleh raja terhadap rakyatnya saat tersebut. Namun, data yang lain menunjukkan bahwa komunitas bahari dapat saja muncul sebelum keberadaan Kerajaan Sriwijaya. Hal ini dikuatkan dengan Prasasti Telaga Batu yang diyakini dituliskan selain menggunakan Bahasa Melayu lama juga mengadopsi Bahasa $B$ atau bahasa yang digunakan oleh Orang Laut tersebut.Wolters sering menyebutkan bahwa telah terjadi kerjasama yang harmonis antara Kerajaan Sriwijaya dengan orang-orang laut ini.Kemampuan orang laut untuk mengarungi lautan serta skill perangnya yang mumpuni menjadikan Sriwijaya dapat disebut berhutang banyak terhadap keberadaan orang laut. Komunitas inilah yang pertama menjadi benteng pertahanan bagi Kerajaan Sriwijaya.

\section{Referensi}

Bronson, Bennet. 1975. Palembang as Srivijaya; The Lateness of Early Cities in Southern Southeast Asia.

Chou, Cynthia. 2016. The Water World of The Orang Suku Laut in Southeast Asia. Sogang
University: Journal of Trans Regional and $\mathrm{Na}$ tional Studies of Southeast Asia vol.4 no.2.

Coedes, Goerge. 1975. The Indianized States of Southeast Asia translated by Susan Brown Cowing. Canberra: Australian National University Press.

Dellios Rosita. Thinking Through Srivijaya; Polycentric Networks in Traditional Southeast Asia.

Forshee, Jill. 2006. Culture and Customs of Indonesia. London: Greenwood Press.

Hamid, Abd Rahman.2018. Sejarah Maritim Indonesia. Yogyakarta: Ombak.

Holt, Claire. 2007. Culture and Politics in Indonesia. Singapura: Equinox Publishing.

Ju-Kua, Chau. 1911. Chau Ju-Kua on the Chinese and Arab Trade in The Twelfth and Thirteenth Centuries translated by Friedrich Hirth. St. Petersburg: Printing Office of The Imperial Academy of Sciences.

Kee-Long, Soo. 1998. Dissolving Hegemony or Changing Trade Pattern? Images of Srivijaya on the Chinese Sources of the Twelfth and Thirteenth Centuries. Singapura: Journal of Southeast Asia Studies Vol. 29 Issue 2.

Kusuma, Pradiptajati. 2017. The Last Sea Nomads of The Indonesian Archipelago: Genomic Origins and Dispersal. Europan Journal of Human genetics.

Manguin, Pierre-Yves. 2008. Welcome to Bhumi Sriwijaya or The Building of Provincial Identity in Contemporaray Indonesia. Singapura: ARI National University Singapore.

Marsanto P., Khidir. 2010. Orang Suku Laut dan Orang Melayu di Kepualuan Riau: Sebuah Tafsir Deskriptif-Etnografis. Depok: Jurnal Antropologi Indonesia vol. 31 no. 3.

Miksic, John. 2010.The Buddhist-Hindu Divide in Premodern Southeast Asia. Singapore: The Nalanda-Sriwijaya Centre.

Muljana, Slamet. 2006. Sriwijaya. Yogyakarta: LkiS.

Munoz, Paul Michel. 2009 Kerajaan-kerajaan Awal Kepulauan Indinesia dan Semenanjung Malaysia terj. Tim Media Abadi. Yogyakarta: Mitra Abadi.

O. W. Wolters. 2011. Kemaharajaan Maritim Sriwijaya \& Perniagaan Dunia Abad III- Abad VII terj. Edy Sembodo. Jakarta: Komunitas Bambu.

Rahman, Abd Rahman.2018. Sejarah Maritim Indonesia. Yogyakarta: Penerbit Ombak. 
Reid, Anthony. 2014. Asia Tenggara Dalam Kurun Niaga 1450-1680 Jilid 1: Tanah di Bawah Angin terj. Mochtar Pabotinggi. Jakarta: Yayasan Pustaka Obor.

2015. Asia Tenggara Dalam Kurun Niaga 1450-1680 Jilid 2: Jaringan Perdagangan Global terj. R. Z. Leirissa, P. Soemitro. Jakarta: Yayasan Pustaka Obor.

Rochmiatun, Endang. 2016. Orang Laut, Bajak Laut dan raja Laut; Dinamika Kehidupan dan Kekuasaan dalam Naskah Kontrak Sultansultan Palembang Abad 18-19. Depok: Jurnal Manuskripta vol. 6 no. 1.

Sastri, K. A. Nilakanta. 1949. History of Sri Vijaya. India: University of Madras Press. South Indian Influences in The Far East. India: Hind Kitab Ltd. Tanpa tahun.

Sather, Clifford. Sea Nomads and Rainforest Hunter-Gatherers: Foraging Adaptattions in the Indo-Malaysian Archipelago.

Suhaimi, Nik Hasan. 1991. Port and Polity of The Malay Peninsula and Sumatra (5th-14th Centuries A.D.). Surabaya: International Seminar "Harbour Cities along the Silk Roads.

T. Kao, William. 1956. A Primary Chinese Record Relating to Ho-Lo-Tan and Miscellaneous Notes on Srivijaya and Fo-Che Vol. 29 No.1. Kuala Lumpur: Journal of Malayan Branch of Royal Asiatuc Society.

Tarling, Nicholas, ed. 1994. The Cambridge History of Southeast Asia Vol. I: From Early Times to c. 1800. UK: Cambridge University Press.

Taylor, Jean German. 2003. Indonesia; Peoples and Histories. Yale: Yale University Press.

Tim Nasional Penulisan Sejarah Indonesia. 2010.Sejarah Nasional Indonesia Jilid II: Zaman Kuno. Jakarta: Balai Pustaka.

Tsing, I. A Record of The Buddhist Religion as Practiced in India and The Malay Archipelago translated by Takakusu. London: Oxford University Press.

Wolters, O.W. 1990. Kejatuhan Srivijaya dalam Sejarah Melayu terj.Toh Kim Hui. Kuala Lumpur: Dewan Bahasa dan Pustaka Kementerian Pendidikan Malaysia.

Landfall of The Palembang Coast in Medieval Times.

Woodward, Mark. 2011. Java, Indonesia, and Islam. London: Springer.
${ }^{1}$ Nicholas Tarling, ed.The Cambridge History of Southeast Asia Vol. I: From Early Times to c. 1800. (UK: Cambridge University Press, 1994) hlm. 197.

${ }^{2}$ Geomorfologi adalah sebuah cabang ilmu Geografi yang di dalamnya membahas tentang bentuk permukaan dari bumi dan perubahan-perubahn yang terjadi padanya dari masa ke masa.

'Slamet Muljana, Sriwijaya (Yogyakarta: Penerbit LKiS, 2011), hlm. 119.

${ }^{4}$ Abdur Rahman Hamid, Sejarah Maritim Indonesia. (Yogyakarta; Penerbit Ombak, 2018), hlm. 9.

${ }^{5}$ Lihat Sather, Clifford (2007); Sea Nomads and Rainforest Hunter-Gatherers: Foraging Adaptations in the Indo-Malaysian Archipelago, in Bellwood, P., Fox, J. J., Tryon, D (ed.) The Austronesians: Historical and Comparative Perspectives. Canberra: ANU E Press.

${ }^{6}$ Diakses dari https://www.theguardian. com/global-development/2014/dec/10/indian-ocean-tsunami-moken-sea-nomads-thailandpada 25 Juli 2018.

${ }^{7}$ Diakses dari http://www.bbc.com/future/story/20160229-the-sea-nomad-childrenwho-see-like-dolphinspada 26 Juli 2018.

${ }^{8}$ Clifford Sather, Sea Nomads and Rainforest......

${ }^{9}$ Ibid.,

${ }^{10}$ Nicholas Tarling, The Cambridge History of Southeast Asia..., hlm. 198-199.

${ }^{11}$ Chau Ju-Kua, Chau Ju-Kua; His Work on the Chinese and Arab Trade in The Twelfth and Thriteenth Centuries, Entitled Chu-fan-chi. Translated by Friedrich Hirth \& W.W. Rockhill (St,. Petersburg: Printing Office of The Imperial Academy of Sciences, 1911), hlm. 60.

${ }^{12} \mathrm{Ibid}$, hlm. 64.

${ }^{13} \mathrm{Abd}$ Rahman Hamid, Sejarah Maritim Indonesia (Yogyakarta; Penerbit Ombak, 2018), hlm. 7.

${ }^{14}$ Ibid.

${ }^{15}$ Lihat dalam Suhaimi, Nik Hasan. Port and Polity of The Malay Peninsula and Sumatra (5th-14th Centuries A.D.). Surabaya: International Seminar "Harbour Cities along the Silk Roads.1991.

${ }^{16}$ Ibid.,

${ }^{17}$ Tymothy P. Barnard, Celates, Rayat-Laut, Pirates; The Orang Laut and Their Decline in History, (Kuala Lumpur: Journal MBRAS Vol 80 part 2, 2007), hlm. 35.

${ }^{18}$ Ibid.,
${ }^{19}$ Ibid., 